Васильев В. Л. Еще раз о происхождении названий реки Вятка и города Вятка (совр. Киров) // Вопр. ономастики. 2016. Т. 13. № 2. С. 23-39.

ЭСБМ - Этымалагічны слоўнік беларускай мовы / ред. Г. А. Цыхун. Мінск, 1978-. T. 1-.

ЭСРДС - Аникин А. Е. Этимологический словарь русских диалектов Сибири: заимствования из уральских, алтайских и палеоазиатских языков. М. ; Новосибирск, 2000.

ЭССЯ - Этимологический словарь славянских языков: Праславянский лексический фонд / под ред. О. Н. Трубачева (вып. 1-32); А. Ф. Журавлева (вып. 33-39); Ж. Ж. Варбот (вып. 40-). М., 1974-. Вып. 1-.

DOI 10.31168/7996-2700-3.68

\author{
И. А. Кюршунова \\ Институт языка, литературы и истории КарНЦ РАН \\ Петрозаводский государственный университет \\ Петрозаводск, Россия \\ kiam24@mail.ru
}

\title{
Региональный ономастикон донационального периода как источник этнокультурной информации*
}

Включение ономастического материала в этнокультурную исследовательскую сферу продолжает оставаться актуальным и востребованным знанием. Это обусловлено самой природой имени собственного, являющегося культурным кодом эпохи с уже сложившимися и меняющимися традициями. Анализ донационального ономастикона, представленного в письменных источниках определенного региона, дает возможность взглянуть на вопросы, связанные с этнокультурной составляющей прошлого, с разных точек зрения: «универсальное специфическое», «свое - чужое», «центр - периферия», «индивид семья - социум» (их аксиологические установки).

В докладе рассматриваются имена собственные, зафиксированные в делопроизводственных документах Карелии XV-XVII вв. - периферийной, разноэтнической, архаической (даже по меркам изучаемого

\footnotetext{
* Исследование выполнено при финансовой поддержке РФФИ, проект № 18-012-00810.

(С) Кюршунова И. А., 2019
} 
времени), трансграничной территории. Особое внимание уделено ономастическим единицам, представляющим прямо или косвенно человека: личным (некалендарным и календарным) именам, прозвищам, патронимам, отчествам, фамильным прозваниям, посессивным ойконимам.

Несмотря на то, что центральную позицию для указанного времени занимают личные имена, каждая ономастическая единица по отдельности и в группе является сгустком этнокультурной информации, имеющей свои особенности.

Использование н екаленд д рных личных и мен (Бажен, Ждан, Нечай, Подосенко, Третьяк) как уходящей части ономастикона - показатель многогранных семейных ценностей (верований, обычаев, связанных с рождением, иерархическим положением членов семьи), определяющих место этой ономастической единицы в мировоззренческой картине прошлого.

Каленндарны е личны е и м ен а (в любой форме) представляют иной информационный ресурс, ориентированный на христианские ценности; при этом в мотивационном плане возможно видеть и прежние охранные темы, что еще теснее связывает их в функциональном плане с предыдущей антропонимической группой.

П р о з в и щ а (Базыка, Варач, Гундор, Дериба, Заляка) продуцируют отношения в социуме. Их несомненная близость к апеллятивной лексике (особенно экспрессивной, практически не представленной в текстах документов донационального периода) ставит эти антропонимические единицы на более высокий уровень в деле выяснения этнокультурной информации, которая определяет важные аспекты внешнего и внутреннего мира человека (прежде всего в рамках региона, хотя сами выдвигаемые социумом требования - следование норме, стремление к идеалу, отношение к труду и пр. - являлись общезначимыми).

В ряде случаев единственными свидетелями ранее существовавших личных имен и прозвищ, а следовательно, и этнокультурной информации, заключенной в них, являются п а т о н и мы и п о с е с с и в н ы е о й ко н и мы. Например, именно в их основах сохранилась бо́льшая часть имен с финно-угорскими маркерами, ср. названия деревень Кяргиева селга, Лявкуево, на Кик-озере словет Лукинская Питкуева, Тиркоев наволок. Кроме того, эти онимы отмечали принадлежность, отношение человека к семейному социуму, а посессивный ойконим еще и закреплял его за определенной территорией. 
Таким образом, региональный ономастический материал донационального периода несет через имя этнокультурную информацию о человеке, его месте в мире, его основных приоритетах в семье и обществе.

DOI $10.31168 / 7996-2700-3.69$

\author{
Н. В. Лабунец \\ Тюменский государственный университет \\ Тюмень, Россия \\ labunetsn@gmail.com
}

\title{
Топонимия нижнего течения реки Тавды: историко-этимологический ракурс
}

Топонимия бассейна реки Тавды представляет особый интерес не только в аспекте лингвоэтнического взаимодействия, но и с позиций реконструкции обско-угорского субстрата. Тавдинская топонимия изучена неравномерно: развернутые исследования под руководством А. К. Матвеева были проведены по верхнему и среднему течению учеными УрФУ (УрГУ): начиная с 1960-х гг. - М. Т. Муминовым и Г. В. Глинских, на рубеже XX-XXI вв. - О. В. Смирновым и др. Результатом стали уникальные лексикографические базы, в которых представлен топонимический материал вымершего южного (тавдинского) диалекта мансийского языка.

Несмотря на сложившиеся традиции, изучение географических названий по нижнему течению р. Тавда практически не проводилось, хотя отдельные топонимические наблюдения в ходе полевых диалектологических работ были сделаны еще в 1950-е гг. М. А. Романовой, в 1970-е гг. Т. Н. Дмитриевой, позже - тюркологами Д. Г. Тумашевой и Х. Ч. Алишиной.

Цель настоящей работы - выявить и этимологически прокомментировать обско-угорские элементы в составе гидронимов нижнего течения р. Тавда (Нижнетавдинский район Тюменской обл.). Источником послужили личные записи автора, собранные в 2003-2005 гг. в русских старожильческих поселениях Нижнетавдинского района, а также исторические и историко-картографические материалы XVIII-XIX вв. (C) Лабунец Н. В., 2019 